\title{
The strategy of raising the courage of girls through folklore
}

\author{
Arianti K ${ }^{1}$, Sulistyaningsih ${ }^{2}$ dan Nanny Sri Lestari ${ }^{3}$ \\ \{1 ariantii-@hotmail.com, ${ }^{2}$ tyaoreo99@gmail.com, ${ }^{3}$ nanny-sl@ui.ac.id \\ 123 Universitas Indonesia
}

\begin{abstract}
Every nation in the world has features that are passed on to its young generation. These features can take various forms. One of them is folklore. This study discusses thinking strategies embodied by the Javanese traditional community, in an effort to lift the courage of girls in facing life's challenges. It is well known that girls are personal figures who later will be responsible for managing the household and educating children. The focus of this research is to discuss two folktales that illustrate the struggle of girls in facing life's difficulties. The struggle for life must be faced with rigid because it already has no other choice. The purpose of this study is to bring up traditional community techniques in giving encouragement to girls. This strong encouragement must be taught to girls on the grounds that girls have a great responsibility in managing the household and educating children. This study uses a qualitative research paradigm procedure. Based on data collected from 4 stories (folklore) there is a similar condition. First, girls become the main characters of the story. Secondly, in the story line girls are always described as facing the challenges of continuous life difficulties. Third, in the story, the characters must be strong in facing various kinds of difficulties. Fourth, the story setting always takes place in a public place like in a village. Fifth, the storyline ends with happiness. The results show that, these five technical arrangements are a powerful way to enter story messages to the reader or listener of the story. The result is that all four stories can be accepted by the community and become very popular in the community. These four stories are a good example, for every girl to remain strong in facing the challenges of difficulties in her life.
\end{abstract}

Keywords: courage, challenges, life, women, obstinacy.

\section{Introduction}

The community lives in two environments namely the natural environment and the cultural environment. In everyday life there are many events that occur. The incident occurred not just once but several times. The events that occur are of course repeated in different times. With this condition the community began to make markers of these recurring events. If the recurring event is of a good nature, it certainly makes the community accept the event and then forget it. But if the recurring event is felt and is not pleasant then the community will make a marker These markers can be physical markers but also non-physical markers. Non-physical signs, 
can be shaped buildings or others, but non-physical markers are usually in the form of stories [1]. This story is used by the community to convey something, both implicit and rapid messages that are explicit. In the perspective of these folklore experts, they can grow in accordance with the conditions of the natural environment and the socio-cultural environment of the people. The people in the archipelago have three pieces of wealth, namely the diversity of life experiences, the rich diversity of the natural environment and the rich diversity of socio-cultural diversity. It is this wealth that often gives color in a study. For example, a story that has the same storyline may have a different background, giving the impression that the stories are different from each other [1].

What will be explored from these four stories is the placement of young women as the main characters of the story. There are 4 folklore stories, namely the story of Keong Mas, Timun Mas, Bawang Merah Bawang Putih and Ande-ande Lumut. These four stories have a number of things in common. The first equation lies in the plot. The story line starts with the difficulties faced by the characters and ends with the happiness obtained by the characters. The second equation lies in the main character of the story. All four stories have the main characters in female stories. The third equation, the setting of the story revolves around the village and in the kingdom. There is only one story that does not mention that the whole series of events is not related to the kingdom, namely the story of Timun Mas. The other three stories, in the series of events in the story are always related to the kingdom, especially at the end of the story. These four folklore main characters are young women. A girl who in their daily lives must face very hard life challenges [2]. These four young women have to face the same hardships in life but in different manifestations. Timun Mas must escape from his house to avoid becoming a victim of a giant who wants to eat Timun Mas. Timun Mas must hide to avoid the giants who chase him. The same thing happened to Bawang Putih in the Bawang Merah and Bawang Putih story. Bawang Putih must stay at the house of the old grandmother to avoid the anger of her stepmother. Somewhat different is the yellow Klenthing story in the Ande-ande Lumut story. Yellow Klenthing, which was treated poorly by her stepmother, managed to defeat Yuyu Kangkang who was not willing to help cross her to the other side of the river. These four stories do have a number of similarities but also have differences.

Related to this research design, previously there have been a number of studies related to the four stories. However, this research is research that only focuses on one story only. Adika, $\mathrm{D}$ [3] examined the function of logical meaning in the Timun Mas folklore. Utami, .AD and NS Lestari [4] conducted a study of the functions, meanings and messages of the natural environment in the story of Keong Mas. Setiawan, Y. B., Fanani, F., \& Julianto, E. N. [5], conducted a narrative analysis on European folklore, Cinderella, with Indonesian folklore, Bawang Merah Bawang Putih. Hari Wibowo, P. N. [6] discusses the story of Ande-Ande Lumut which is an adaptation of folklore into epic theater. This series of studies shows that folklore attracts the attention of researchers, and the research conducted is adjusted to the focus of each researcher.

The purpose of this study is to explore the placement techniques or strategies used by traditional communities. Especially, related to the situation of raising and encouraging the courage of girls. In certain situations and conditions there is indeed an assumption that girls often face challenges in life's difficulties. These four stories have the main characters of young women. In these four stories, young women are described as young women characters who have struggled with difficulty in their lives. The main focus of this research is to open up one side that has often been ignored by the community related to this story. This story is actually not just ordinary folklore, but there is one thing that is intended from this story. This is to inform and prepare girls who have begun to reach adolescence about the struggles that must be 
faced in family and community life. Described in all four stories, the young woman must avoid one enormous difficulty which is manifested in a giant form. The great difficulties in life are considered comparable to the physical form of the giant. It means as if a giant is a symbol of all kinds of difficulties. Such is the magnitude of the difficulties of life faced by young women, communities with creative creativity create stories that encourage young women to dare to face difficulties. To understand all of these problems, this research cannot be carried out from only one angle of science. As a story, this research will be seen from the perspective of literary, environmental and cultural approaches. For the reason of these four stories has a certain literary, cultural and environmental background [7].

These three things are very important to discuss because in order to fully understand the way of thinking and the perspective of the community, especially those related to the strategy of raising the courage of girls or young women through folklore. In finding this strategy, of course there are a number of steps that must be considered. The work steps are arranged according to the approach applied in this study. Starting with the structure of the story, the role of the main characters in the story is related to the community environment and aspects of community life documented in culture.

\section{Research Method}

In tracing the strategy of raising the courage of girls through a number of folklore, this study uses a qualitative research paradigm procedure. Qualitative research is research that utilizes all data collected in inductive and deductive ways. The data can be intrinsic or extrinsic By using qualitative research, researchers can interpret the available data, especially in relation to research on oral literature. The study was conducted on the basis of a textual approach to a number of folklore which in this case had been written in the form of a story script [8]. To complete the analysis of the content of the story, it needs a review of the structure of the story in which there is a story line. The story line contains a series of events related to the character of the story and the setting of the story. To understand it as a whole of the function and meaning of folklore also requires an approach to the natural environment that is reflected in literary works. With the eco-literary approach it is intended that the function and meaning of the natural environment in folklore can be understood in its entirety as a cultural monument. Furthermore, the functions and meaning of the natural environment will be analyzed philosophically based on the local wisdom of the local community .

\section{Results And Discussion}

\subsection{The main characters in the story}

In folklore the community builds the character of a story based on its understanding of the environmental system unit. The characters in a story do not always have to be strong but can also be gentle. The characters of the story are arranged based on community knowledge, community desires and norms prevailing in society, such as people's views of the elements of character, including personality, behavior, character, daily habits or livelihoods and the environment decorate all parts of the story. That is why it can happen that one particular story character has similarities with other story characters [9]. 
The basis of forming the main characters in folklore is the view that the story can be accepted by all parties in society. The characters are compiled based on daily life, also equipped with an inner emotional atmosphere of the people in the place. In characterizing both women and men in folklore there is a moral measure that is highly upheld. The moral measure can be seen from the giving of character identity. In this situation the psychological condition of the character of the story built by the community can be seen. An example is the story of Timun Mas. The identity or name of Timun Mas, refers to the character of a woman's story. Besides the word Timun (cucumber) also refers to the types of plants whose fruits are green and fresh. The word Mas is an equivalent word, which is placed next to the word Timun (cucumber) to show something special. The setting contained in this story is also very specific, namely the tropics where the cucumber plants can flourish. For the record, in some areas the Timun Mas story refers to a fruit called Timun suri, which is usually crowded with people in the fasting month.

\subsection{The position of girls in the family}

As in general the lives of people in other regions, many people in the archipelago also adhere to patriarchal kinship lines [10]. This patriarchal kinship line causes boys to get more attention than girls. Actually, if traced carefully based on the environment, this condition is not surprising. But over time and times have changed so many changes that are no longer in accordance with the situation. Both boys and girls should receive the same attention [11]. Recognizing the difficult conditions of changing people's viewpoints, the older generation began to compile fables based on living conditions or life challenges that must be faced by girls in society. If the conditions are described to be like this,

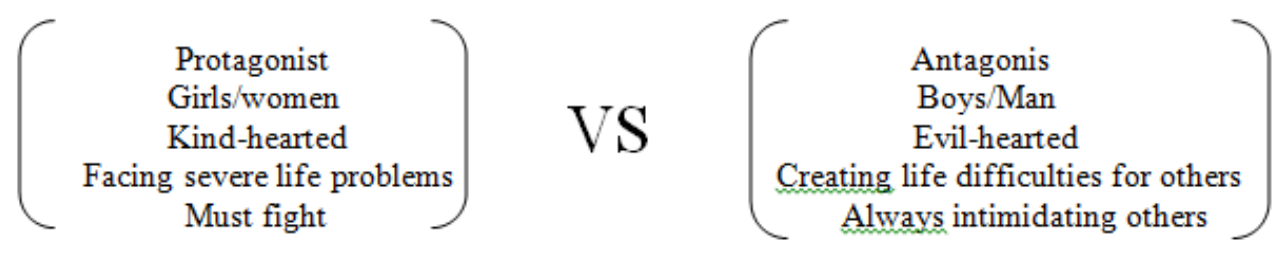

In these four tales, the fate of the girls in their teens is always told. Girls have to face very difficult life challenges. To illustrate the challenges of life that is very heavy, the older generation analogizes the challenges of life that are heavy with a giant embodiment. Giant means something big. Something big can be good or bad, in the relation to the four stories, of course, evil giants. From the series it can be seen that there is a certain pattern built into one story. The pattern of the story is shown through the characters that play a role in a series of events (in the storyline) is very difficult to be changed into a different character. The protagonist who is always female is always confronted with the male antagonist, so that there are two poles that are different from each other [12]. These two different things show that there are two poles of difference that seem like days and nights.

\subsection{Give encouragement to girls}

The fact that girls have to face more difficult life challenges, becomes a reality illustrated in the four folklore. If analogous to the four stories that have similarities as well as quite interesting differences, like the diagram below, 
Table 1: The camparation story

\begin{tabular}{|c|c|c|c|c|c|}
\hline No: & $\begin{array}{l}\text { Story } \\
\text { description }\end{array}$ & $\begin{array}{l}\text { Timun Mas's } \\
\text { Story }\end{array}$ & $\begin{array}{l}\text { Keong Mas's } \\
\text { Story }\end{array}$ & $\begin{array}{l}\text { Ande-ande Lumut's } \\
\text { Story }\end{array}$ & $\begin{array}{l}\text { Bawang } \\
\text { Merah and } \\
\text { Bawang } \\
\text { putih's story }\end{array}$ \\
\hline 1 & Storyline: & $\begin{array}{l}\text { forward or } \\
\text { linear grooves }\end{array}$ & $\begin{array}{l}\text { forward or } \\
\text { linear grooves }\end{array}$ & $\begin{array}{l}\text { forward or linear } \\
\text { grooves }\end{array}$ & $\begin{array}{l}\text { forward or } \\
\text { linear grooves }\end{array}$ \\
\hline 2 & $\begin{array}{l}\text { Character } \\
\text { Story: } \\
\text { Protagonist } \\
\text { Antagonist }\end{array}$ & $\begin{array}{l}\text { - Timun Mas } \\
\text { - Buto Ijo }\end{array}$ & $\begin{array}{l}\text { - Keong Mas } \\
\text { - Raksasa jahat }\end{array}$ & $\begin{array}{l}\text { - Klenting kuning } \\
\text { - Yuyu Kangkang }\end{array}$ & $\begin{array}{l}\text { - Stepmother } \\
\text { and cruel } \\
\text { bawang merah } \\
\text { - Bawang } \\
\text { putih }\end{array}$ \\
\hline 3 & $\begin{array}{l}\text { Background } \\
:\end{array}$ & $\begin{array}{l}\text { Rural } \\
\text { environment, } \\
\text { rice fields, river } \\
\text { gardens and } \\
\text { forests }\end{array}$ & $\begin{array}{l}\text { Rural } \\
\text { environment, } \\
\text { rice fields, river } \\
\text { gardens and } \\
\text { forests }\end{array}$ & $\begin{array}{l}\text { Rural environment, } \\
\text { rice fields, river } \\
\text { gardens and }\end{array}$ & $\begin{array}{l}\text { Rural } \\
\text { environment, } \\
\text { rice fields, } \\
\text { river gardens } \\
\text { and forests }\end{array}$ \\
\hline 4 & $\begin{array}{l}\text { The } \\
\text { massage of } \\
\text { the story: }\end{array}$ & $\begin{array}{l}\text { Raise the } \\
\text { courage of girls } \\
\text { in facing life. }\end{array}$ & $\begin{array}{l}\text { Raise the } \\
\text { courage of girls } \\
\text { in facing life. }\end{array}$ & $\begin{array}{l}\text { Raise the courage of } \\
\text { girls in facing life. }\end{array}$ & $\begin{array}{l}\text { Raise the } \\
\text { courage of } \\
\text { girls in facing } \\
\text { life. }\end{array}$ \\
\hline
\end{tabular}

From these comparison, all four stories emphasize the ability of girls to struggle with different life challenges, but the core life challenges they face are the same. This condition shows that hard life is not only experienced by men but women also face quite hard life problems. The hardships of life challenges faced by girls are not only based on the harshness of the natural environment but also the harshness of the family environment and the natural environment.

From the results of the four studies that have been made in the table above it can be seen that there is one element that is independent of previous research [14]. What escapes the attention of previous research is the message behind the four stories. The message is a direct message that girls must be able to face life's struggles. This story seems simple, but if the focus of the four stories is observed well, then there is a message that happiness can be achieved through effort that is not easy. In everyday life, without realizing that the story is only focused on the past in the agricultural area. This condition is not as predicted. This story could have happened in the past or in the present. Both in areas with agricultural environments and other social environments [13].

On the other hand, life is not like the beauty of a daydreaming condition of life's struggle [14]. Many other fairy tales also revolve around the struggle in facing life's challenges that are quite heavy, but most of the characters are more interesting stories if the role is female characters. In most of the world community, women have a special role, namely the role of developing the quality of human life. In fact in society it is recognized that women have a large and very important role, both in the family and in society. It's just that this confession is not done explicitly but stated in the form of an implicit acknowledgment. Implicit recognition means that in everyday life fairy tales or stories are composed while still raising the important role of women in the family and society. Women are considered as an activator of family life as well as a motivator of the dynamics of family and community life.

Tension in the dynamics of family and community life becomes the main menu to be processed into a story, while the condition of the natural environment is often used as a tool to 
trigger changes in behavior of the character of the story. This situation results in dynamics in the interaction between story characters. There is often a misunderstanding of thought which states that women are the object of the story. This misunderstanding of thought occurs due to people who always think that men are the main subject of life while women are the objects of life itself [15]. As a result of the awareness that men and women have the same position and even women tend to have a greater portion of roles and responsibilities, then a solution is made by making stories that try to give greater attention to women.

\section{Conclusion}

These four stories show that women are individual figures who have a very large role and position in the family. Women from childhood have to be introduced to situations that will later be faced in their lives. It's not easy, almost all traditions in society always teach things that are nature to scare women. For this reason, it is necessary to explain that the feared matter must be resisted, not must be accepted with surrender. The thing that must be explained is the ability of women in everyday life. Indeed, to explain this is indeed not easy, especially since this condition has been going on for years, so it is not an easy thing to explain it. For one way is needed to lift the courage of women in facing the challenges of life is very heavy. The way is by creating folklore that can lift the spirit of courage of girls. The result is indeed a very simple story but it is never boring to repeat. This story is not just a child story that looks simple, but this story has a message about the mental condition of girls that must be prepared before becoming a female adult.

Society has a living system in which there is a network of elements related to one another. These elements are a unit of thought embodied in the reality of everyday behavior patterns. Society does have the same point of view, but in reality daily life often results in sharp disagreements. In order to divert differences of opinion, stories are made that neutralize these differences of opinion. Differences of opinion are mainly related to the role and position of girls in the family and community.

\section{References}

[1] L. . Wachidah, H. Suwignyo, and N. Widiati, "Potensi Karakter Tokoh dalam Cerita Rakyat sebagai Bahan Bacaan Literasi Moral," J. Pendidik. Teor. Penelitian, dan Pengemb., 2017.

[2] A. S. Padmanugraha, "Common Sense Outlook on Local Wisdom and Identity :A Cobtemporary Javanese Native's Experience," Int. Conf. Local Wisdom Character Build., 2010.

[3] D. Adika, "TELAAH FUNGSI MAKNA LOGIS PADA CERITA RAKYAT TIMUN EMAS DAN TERJEMAHANNYA," PRASASTI J. Linguist., 2018.

[4] A. B. Utami and N. S. Lestari, "FUNCTION, MEANING, AND MESSAGE OF THE NATURAL ENVIRONTMENT IN THE STORY OF KEONG MAS,” Int. Rev. Humanit. Stud., 2019.

[5] Y. B. Setiawan, F. Fanani, and E. N. Julianto, "Bias Gender Dalam Cerita Rakyat: (Analisis Naratif pada folklore Eropa, Cinderella, dengan Cerita Rakyat Indonesia, Bawang Merah Bawang Putih)," J. Messenger, 2016.

[6] P. N. Hari Wibowo, "Ande-Ande Lumut: Adaptasi Folklor ke Teater Epik Brecht," Resital J. Seni Pertunjuk., 2013.

[7] J. W. Creswell and V. L. Plano-Clark, "Choosing a mixed methods design," Des. Conduct. Mix. Method Res., 2011. 
[8] L. Dsikowitzky et al., "Java Island, Indonesia," in World Seas: an Environmental Evaluation, 2019.

[9] L. Harvilahti, "Folklore and Oral Tradition," Oral Tradit., 2004.

[10] A. C. Budiati, "Aktualisasi Diri Perempuan Dalam Sistem Budaya Jawa (Persepsi Perempuan terhadap Nilai-nilai Budaya Jawa dalam Mengaktualisasikan Diri)," Pamator, 2010.

[11] S. Soedjijono and E. Susilo, "A Prose Fiction Theory Of Javanese Literature Based on Folktales," ATAVISME, 2014.

[12] N. Worth, "Feeling precarious: Millennial women and work," Environ. Plan. D Soc. Sp., 2016.

[13] S. M. Kushendrawati, "Wayang dan Nilai-nilai Etis: Sebuah Gambaran Sikap Hidup Orang Jawa," Paradig. J. Kaji. Budaya, 2016.

[14] Y. M. Raharjo, S. Suwandi, and K. Saddhono, "The Values of Character Education in a novel Nun: Pada Sebuah Cermin by Afifah Afra," Hortatori J. Pendidik. Bhs. dan Sastra Indones., vol. 1, no. 2, pp. 179-186, 2017.

[15] K. Saddhono, "Cultural and Social Change of Foreign Students in Indonesia: The Influence of Javanese Culture in Teaching Indonesian to Speakers of Other Languages (TISOL)," in IOP Conference Series: Earth and Environmental Science, 2018, vol. 126, no. 1. 